medRxiv preprint doi: https://doi.org/10.1101/2022.01.25.22269839; this version posted January 28,2022 . The copyright holder for this preprint (which was not certified by peer review) is the author/funder, who has granted medRxiv a license to display the preprint in

All rights reserved. No reuse allowed without permission.

\title{
EPIDEMIOLOGICAL CHARACTERISTICS AND SEVERITY OF OMICRON VARIANT CASES IN THE APHP CRITICAL CARE UNITS
}

\section{THE APHP REALITY RESEARCH GROUP}

Antoine Vieillard-Baron ${ }^{1}$, Rémi Flicoteaux ${ }^{2}$, Maud Salmona ${ }^{3}$, Djillali Annane ${ }^{4}$, Soufia Ayed ${ }^{5}$, Elie Azoulay 6 , Raphael Bellaiche ${ }^{7}$, Sadek Beloucif ${ }^{8}$, Enora Berti ${ }^{9}$, Astrid Bertier ${ }^{9}$, Sébastien Besset ${ }^{10}$, Marlène Bret ${ }^{11}$, Alain Cariou $^{12}$, Christophe Carpentier ${ }^{5}$, Oussama Chaouch ${ }^{13}$, Appoline Chariot ${ }^{2}$, Cyril Charron $^{1}$, Julien Charpentier ${ }^{12}$, Cherifa Cheurfa ${ }^{14}$, Bernard Cholley ${ }^{13}$, Sébastien Clerc ${ }^{15}$, Alain Combes ${ }^{16}$, Benjamin Chousterman ${ }^{17}$, Yves Cohen $^{18}$, Jean-Michel Constantin ${ }^{19}$, Charles Damoisel ${ }^{20}$, Michael Darmon $^{6}$, Vincent Degos ${ }^{19}$, Bertrand De Maupeou D'Ableiges ${ }^{2}$, Sophie Demeret ${ }^{21}$, Etienne De Montmollin ${ }^{22}$, Alexandre Demoule ${ }^{15}$, Francois Depret ${ }^{23}$, Jean-Luc Diehl ${ }^{24}$, Michel Djibré25, Chung-Hi Do ${ }^{21}$, Emmanuel Dudoignon ${ }^{19}$, Jacques Duranteau ${ }^{26}$, Muriel Fartoukh $^{25}$, Fabienne Fieux ${ }^{27}$, Etienne Gayat ${ }^{17}$, Mael Gennequin ${ }^{28}$, Bertrand Guidet ${ }^{29}$, Christophe Gutton $^{27}$, Sophie Hamada ${ }^{13}$, Nicholas Heming ${ }^{4}$, Romain Jouffroy ${ }^{1}$, Hawa Keita-Meyer ${ }^{30}$, Olivier Langeron ${ }^{7}$, Brice Lortat-Jacob ${ }^{31}$, Jonathan Marey ${ }^{32}$, Alexandre Mebazaa ${ }^{17}$, Bruno Megarbane ${ }^{33}$, Armand Mekontso-Dessap ${ }^{9}$, Jean-Paul Mira ${ }^{12}$, Julie Molle ${ }^{11}$, Nicolas Mongardon ${ }^{7}$, Philippe Montravers ${ }^{31}$, Capucine Morelot-Panzinii ${ }^{11}$, Safaa Nemlaghi $^{15}$, Bao-long Nguyen ${ }^{19}$, Antoine Parrot ${ }^{34}$, Romain Pasqualotto ${ }^{19}$, Nicolas Peron ${ }^{24}$, Lucile Picard ${ }^{7}$, Marc Pineton de Chambrun ${ }^{16}$, Benjamin Planquette ${ }^{35}$, Benoit Plaud ${ }^{23}$, Stéphanie Pons ${ }^{19}$, Christophe Quesnel ${ }^{27}$, JeanHerlé Raphalen ${ }^{30}$, Keyvan Razazi ${ }^{9}$, Jean-Damien Ricard ${ }^{10}$, Anne Roche ${ }^{36}$, Benjamin Rohaut ${ }^{21}$, Damien Roux ${ }^{10}$, Laurent Savale $^{36}$, Jennifer Sobotka ${ }^{37}$, Jean-Louis Teboul ${ }^{5}$, Jean-François Timsit ${ }^{22}$, Guillaume Voiriot ${ }^{25}$, Emmanuel Weiss ${ }^{28}$, Lucille Wildenberg ${ }^{26}$, Elie Zogheib ${ }^{8}$, Bruno Riou ${ }^{38}$, Frédéric Batteux ${ }^{39}$

\section{Corresponding author}

Prof Antoine Vieillard-Baron

Service de Médecine Intensive Réanimation

University Hospital Ambroise Paré, APHP, Boulogne-Billancourt, France

9 avenue Charles de Gaulle, 92100 Boulogne, France

Tel: +33149095605

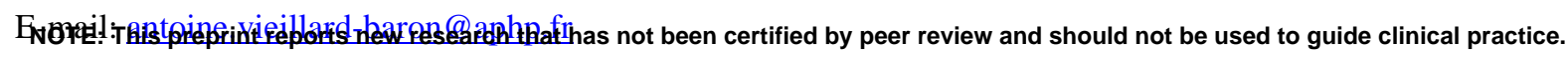


medRxiv preprint doi: https://doi.org/10.1101/2022.01.25.22269839; this version posted January 28,2022 . The copyright holder for this preprint (which was not certified by peer review) is the author/funder, who has granted medRxiv a license to display the preprint in All rights reserved. No reuse allowed without permission.

1 Service de Médecine Intensive Réanimation, Université Versailles Saint-Quentin en Yvelines, Hôpital Ambroise Paré, APHP

2 Département d'information médicale, APHP

3 Laboratoire de Virologie, Université de Paris, Hôpital Saint-Louis, APHP

4 Service de Médecine Intensive Réanimation, Université Versailles Saint Quentin en Yvelines, Hôpital Raymond Poincaré, APHP

5 Service de Médecine Intensive Réanimation, Université Paris-Saclay, Hôpital Bicêtre, APHP

6 Service de Médecine Intensive Réanimation, Université de Paris Hôpital Saint Louis, APHP

7 Département d'Anesthésie et de Réanimation, Université Paris Est Créteil, Hôpital Henri Mondor, APHP

8 Département d'Anesthésie et de Réanimation, Université Sorbonne Paris Nord, Hôpital Avicenne, APHP

9 Service de Médecine Intensive Réanimation, Université Paris Est Créteil, Hôpital Henri Mondor, APHP

10 Service de Médecine Intensive Réanimation, Université de Paris, Hôpital Louis Mourier, APHP

11 Service de Pneumologie, Département R3S, Sorbonne Université, Hôpital Pitié Salpêtrière, APHP

12 Service de Médecine Intensive Réanimation, Université de Paris, Hôpital Cochin, APHP

13 Département d'Anesthésie et de Réanimation, Université de paris, Hôpital HEGP, APHP

14 Département d'Anesthésie et de Réanimation, Université de Paris, Hôpital Cochin, APHP

15 Service de Pneumologie et Réanimation Médicale du Département R3S, Sorbonne Université, Hôpital Pitié Salpêtrière, APHP

16 Service de Médecine Intensive Réanimation, Institut de Cardiologie, Université de Paris, Hôpital Pitié Salpêtrière, APHP

17 Département d'Anesthésie et de Réanimation, Université de Paris, Hôpital Lariboisière, APHP

18 Service de Médecine Intensive Réanimation, Université Sorbonne Paris Nord, Hôpital Avicenne, APHP

19 Département d'Anesthésie et de Réanimation, Sorbonne Université, Hôpital Pitié Salpêtrière, APHP

20 Département d'Anesthésie et de Réanimation, Université Paris-Saclay, Hôpital Antoine Béclère, APHP

21 Service de Réanimation neurologique, Sorbonne Université, Hôpital Pitié Salpêtrière, APHP

22 Service de Médecine Intensive et Réanimation infectieuse, Université de Paris, Hôpital Bichat, APHP

23 Département d'Anesthésie et de Réanimation, Université de Paris, Hôpital Saint-Louis, APHP

24 Service de Médecine Intensive Réanimation, Université de Paris, Hôpital HEGP, APHP

25 Service de Médecine Intensive Réanimation, Université de Paris, hôpital Tenon, APHP

26 Département d'Anesthésie et de Réanimation, Université Paris-Saclay, Hôpital Bicêtre, APHP 
medRxiv preprint doi: https://doi.org/10.1101/2022.01.25.22269839; this version posted January 28,2022 . The copyright holder for this preprint (which was not certified by peer review) is the author/funder, who has granted medRxiv a license to display the preprint in All rights reserved. No reuse allowed without permission.

27 Département d'Anesthésie et de Réanimation, Sorbonne Université, Hôpital Saint Antoine et Tenon, APHP

28 Département d'Anesthésie et de Réanimation, Université de Paris, Hôpital Beaujon, APHP

29 Service de Médecine Intensive Réanimation, Sorbonne Université, Hôpital Saint Antoine, APHP

30 Département d'Anesthésie et de Réanimation, Université de Paris, Hôpital Necker, APHP

31 Département d'Anesthésie et de Réanimation, Université de Paris, Hôpital Bichat, APHP

32 Service de Pneumologie, université de Paris, Hôpital Cochin, APHP

33 Service de Médecine Intensive Réanimation, Université de Paris, Hôpital Lariboisière, APHP

34 Service de Pneumologie, Sorbonne Université, Hôpital Tenon, APHP

35 Service de Pneumologie, Université de Paris Hôpital HEGP, APHP

36 Service de Pneumologie et soins intensifs, Université Paris-Saclay, Hôpital Bicêtre, APHP

37 Service des Urgences, Sorbonne Université, Hôpital Saint Antoine, APHP

38 Service d'Accueil des Urgence, Sorbonne Université, Hôpital Pitié Salpêtrière

39 Service d'immunologie Université de Paris, Hôpital Cochin and direction de la stratégie et de la transformation,

APHP 
medRxiv preprint doi: https://doi.org/10.1101/2022.01.25.22269839; this version posted January 28,2022 . The copyright holder for this preprint (which was not certified by peer review) is the author/funder, who has granted medRxiv a license to display the preprint in All rights reserved. No reuse allowed without permission.

\section{Abstract \\ Importance}

Information about the severity of Omicron is scarce.

\section{Objective}

To report the respective risk of ICU admission in patients hospitalized with Delta and Omicron variants and to compare the characteristics and disease severity of critically ill patients infected with both variants according to vaccination status.

\section{Design}

Analysis from the APHP database, called Reality, prospectively recording the following information in consecutive patients admitted in the ICU for COVID-19: age, sex, immunosuppression, vaccination, pneumonia, need for invasive mechanical ventilation, time between symptom onset and ICU admission, and in-ICU mortality. Retrospective analysis on an administrative database, "Système d'Information pour le Suivi des Victimes" (SI-VIC), which lists hospitalized COVID-19 patients.

\section{Setting}

39 hospitals in the Paris area from APHP group.

\section{Participants}

Patients hospitalized from December 1, 2021 to January 18, 2022 for COVID-19.

\section{Main outcomes and measures}

Risk of ICU admission was evaluated in 3761 patients and Omicron cases were compared to Delta cases in the ICU in 888 consecutive patients.

\section{Results}

On January $18,45 \%$ of patients in the ICU and $63.8 \%$ of patients in conventional hospital units were infected with the Omicron variant $(\mathrm{p}<0.001)$. The risk of ICU admission with Omicron was reduced by $64 \%$ than with Delta $(9.3 \%$ versus $25.8 \%$ of cases, respectively, $\mathrm{p}<0.001)$. In 
medRxiv preprint doi: https://doi.org/10.1101/2022.01.25.22269839; this version posted January 28, 2022. The copyright holder for this preprint (which was not certified by peer review) is the author/funder, who has granted medRxiv a license to display the preprint in All rights reserved. No reuse allowed without permission.

critically ill patients, 400 had the Delta variant, 229 the Omicron variant, 98 had an uninformative variant screening test and 161 did not have information on variant screening test. 747 patients $(84.1 \%)$ were admitted for pneumonia. Compared to patients infected with Delta, Omicron patients were more vaccinated $(\mathrm{p}<0.001)$, even with 3 doses, more immunocompromised $(\mathrm{p}<0.001)$, less admitted for pneumonia $(\mathrm{p}<0.001)$, especially when vaccinated $(62.1 \%$ in vaccinated versus $80.7 \%$ in unvaccinated, $\mathrm{p}<0.001)$, and less invasively ventilated $(\mathrm{p}=0.02)$. Similar results were found in the subgroup of pneumonia but Omicron cases were older. Unadjusted in-ICU mortality did not differ between Omicron and Delta cases, neither in the overall population $(20.0 \%$ versus $27.9 \%, \mathrm{p}=0.08)$, nor in patients with pneumonia (31.6\% versus $29.7 \%$, respectively) where adjusted in-ICU mortality did not differ according to the variant (HR $1.4395 \% \mathrm{CI}[0.89 ; 2.29], \mathrm{p}=0.14)$.

\section{Conclusion and relevance}

Compared to the Delta variant, the Omicron variant is less likely to result in ICU admission and less likely to be associated with pneumonia. However, when patients with the Omicron variant are admitted for pneumonia, the severity seems similar to that of patients with the Delta variant, with more immunocompromised and vaccinated patients and no difference in adjusted in-ICU mortality. Further studies are needed to confirm our results.

Key words: SARS-CoV-2, Omicron variant, intensive care unit, severity 
medRxiv preprint doi: https://doi.org/10.1101/2022.01.25.22269839; this version posted January 28,2022 . The copyright holder for this preprint (which was not certified by peer review) is the author/funder, who has granted medRxiv a license to display the preprint in All rights reserved. No reuse allowed without permission.

\section{Introduction}

Severe acute respiratory syndrome coronavirus 2 (SARS-CoV-2) infection and the resulting coronavirus disease 2019 (COVID-19) have afflicted millions of people in a worldwide pandemic. A new SARS-CoV-2 variant, B.1.1.529, has recently been reported, with the first cases in Botswana and South Africa on November 11 and 14, 2021, respectively. ${ }^{1}$ On November 26, 2021, B.1.1.529, named Omicron, was designated as a variant of concern by the World Health Organization (WHO). ${ }^{2}$ The Omicron variant shares several mutations with previous Alpha, Beta, and Gamma variants of concern, which immediately raised global concerns about viral transmissibility, pathogenicity, and immune evasion. In the Paris region, the Omicron variant represented $4 \cdot 1 \%$ of daily cases on December 7 , but $96.9 \%$ of cases 6 weeks later. ${ }^{3}$

Preliminary studies suggested that Omicron is less severe than other variants. Ferguson et al. reported in the UK a $40 \%$ reduction in the risk of hospitalization ${ }^{4}$ for Omicron cases, while Wolter et al. recently showed an $80 \%$ reduction in South Africa $^{5}$ with no difference in developing severe disease in Omicron cases. In a preliminary report from the electronic administration system of 49 acute care hospitals in South Africa, Maslo et al. suggested that Omicron cases were also less likely to be admitted to the ICU and to receive mechanical ventilation ${ }^{6}$. However, most of these results are based on administrative databases and are strongly related to immune status, including vaccination. Information is still lacking on the characteristics and disease severity of patients admitted to the ICU with the Omicron variant, and on the potential impact of vaccination on disease severity.

All patients admitted to ICUs of the APHP group have been prospectively monitored for COVID-19 since July 2020, leading to a database of more than 7,000 patients. The aim of this study was to compare the characteristics and disease severity of critically ill patients infected with the Omicron and Delta variants according to vaccination status. As APHP also 
medRxiv preprint doi: https://doi.org/10.1101/2022.01.25.22269839; this version posted January 28,2022 . The copyright holder for this preprint (which was not certified by peer review) is the author/funder, who has granted medRxiv a license to display the preprint in All rights reserved. No reuse allowed without permission.

monitors admissions to general medical wards, a further aim was to report the respective risk of ICU admission of patients hospitalized with the Delta and Omicron variants.

\section{Methods}

This study was approved by the ethics and scientific committees of the APHP group (CSE-21-32).

The number of patients admitted to ICUs and to general medical wards was collected on a daily basis from the Système d'Information pour le Suivi des Victimes (SI-VIC) database, which provides real-time data on COVID-19 patients hospitalized in French public and private hospitals (https://www.data.gouv.fr) and was activated for the COVID-19 pandemic on March 13, 2020. ${ }^{7,8}$ As SI-VIC does not provide extensive clinical data on registered patients, in July 2020 we started collecting clinical, vaccinal and virological information from patients admitted to ICUs of the APHP group in the APHP Reality registry.

RT-PCR positivity for SARS-CoV-2 and RT-PCR variant-specific screening tests from patients admitted to ICUs and to general medical wards were collected from the laboratory information system GLIMS® (CliniSys, UK), a software and database shared by all but one virology laboratory of the APHP hospitals. The screening test especially analyzed the following mutations in the SARS-CoV-2 spike protein: L452R (mutation C) and $\Delta 69-70$ or N501Y, or K417N (mutation D). Therefore, C1D0 corresponds to a possible Delta variant and C0D1 corresponds to a possible Omicron variant. ${ }^{9}$ Due to the virological distribution of SARS-CoV2 strains at the time of data analysis, virological results were expressed as Omicron, Delta, or uninformative when screening was impossible, or gave no interpretable results (insufficient viral load), and finally missing. No other variant was observed during the study period.

The Reality database was created in July 2020. It allows intensivists to enter consecutive patients admitted to all the ICUs of APHP group for COVID-19 during the different waves. 
medRxiv preprint doi: https://doi.org/10.1101/2022.01.25.22269839; this version posted January 28,2022 . The copyright holder for this preprint (which was not certified by peer review) is the author/funder, who has granted medRxiv a license to display the preprint in All rights reserved. No reuse allowed without permission.

The following information is collected: age, sex, type of variant, immunosuppression ${ }^{10}$, COVID-19 pneumonia as the reason for admission, time between symptom onset and ICU admission, number of doses of vaccine and the type of vaccine (BNT162b2, mRNA-1273 or other, mostly chAdOx1), invasive mechanical ventilation requirement and finally in-ICU mortality in discharged patients. Only patients with no dose of vaccine were considered unvaccinated, as the natural immunity of patients with 1 dose was unknown.

\section{Statistical analysis}

The respective risk of being admitted to the ICU between December 1, 2021 and January 18, 2022 for Omicron and Delta cases was calculated from the population admitted to hospital for COVID-19 using the administrative database SI-VIC and the laboratory information system GLIMS. Respective characteristics of critically ill Omicron and Delta patients were determined from patients prospectively entered in the Reality registry during the same period.

Categorical data were reported as number and percentage, and medians [Q2, Q3] were reported for continuous data. Information that was not available was treated as missing and no imputation was performed (data were excluded for group comparisons). Percentages were reported as percent of available data (excluding missing values). Comparisons were performed using the Wilcoxon test for continuous variables and the Chi square test for percentages. A survival analysis using a Cox model was performed in the subgroup of critically ill patients with pneumonia including the following variables age, sex, type of variant, immunosuppression, vaccination status and time between symptom onset and ICU admission. The adjusted hazard ratio (aHR) with its $95 \%$ confidence interval $(95 \% \mathrm{CI})$ for the type of variant was reported. A p $<0.05$ was considered significant. Statistical analysis was conducted in R ( $\mathrm{R}$ Core Team 2022). 
medRxiv preprint doi: https://doi.org/10.1101/2022.01.25.22269839; this version posted January 28,2022 . The copyright holder for this preprint (which was not certified by peer review) is the author/funder, who has granted medRxiv a license to display the preprint in All rights reserved. No reuse allowed without permission.

\section{Results}

\section{Results from the administrative database: risk of ICU admission}

From December 1 to January 18, we identified 5140 patients positive for SARS-CoV-2 by RT-PCR. Among them, 1379 (26.8\%) had uninformative variant information and 3761 were positive for either the Delta (1376 patients) or Omicron (2385 patients) variant (Figure 1). Among those 3761 patients, 287 (7.6\%) were initially admitted to the ICU. Of the 1628 patients initially admitted to a general medical ward, $292(17.9 \%)$ were eventually transferred to the ICU. Among the Delta cases ( $\mathrm{n}=1376), 357$ (25.9\%) were admitted to the ICU, either initially or after conventional hospitalization. By contrast, in Omicron cases $(n=2385)$ there was a 64\% reduction in risk of ICU admission directly or after transfer from the ward (222 patients, 9.3\%, $\mathrm{p}<0.001$ versus Delta). The same significant result was observed among patients hospitalized for more than 1 day on the ward, the risk of transfer to the ICU with Omicron being $51 \%$ of that with Delta (20.7\% for Omicron versus $42.2 \%$ for Delta, respectively, $\mathrm{p}<0.001)$. Finally, $1315 / 2385(55.1 \%)$ of Omicron patients finally stayed in the emergency department only and were not admitted to the ICU or to a general medical ward, compared to 531/1376 (38.6\%) for Delta patients $(\mathrm{p}<0.001)$.

The respective dynamics of newly admitted patients per day and the overall number of patients admitted to the ICU and to the general medical ward are reported in Figure 2. Among patients hospitalized in the ICU for COVID-19 on January 18, 45.4\% had an Omicron variant and $37.9 \%$ a Delta variant. The respective values for conventional hospitalizations were $63.8 \%$ and $10.4 \%(\mathrm{p}<0.001)$. 
medRxiv preprint doi: https://doi.org/10.1101/2022.01.25.22269839; this version posted January 28,2022 . The copyright holder for this preprint (which was not certified by peer review) is the author/funder, who has granted medRxiv a license to display the preprint in All rights reserved. No reuse allowed without permission.

\section{Characteristics and disease severity of critically ill patients with Omicron compared to the Delta variant from the prospective Reality database.}

As shown in Table 1, 888 patients were included in Reality between December 1, 2021 and January 18, 2022. In 161 (18\%) patients, we had no variant information. Among the 727 $(82 \%)$ patients with variant information, $98(13.5 \%)$ had an uninformative variant-screening test (insufficient viral load), 400 (55\%) had a Delta variant and 229 (31.5\%) had an Omicron variant. Age and sex were similar in Delta and Omicron cases, while with Omicron patients were more immunocompromised $(34.5 \%$ versus $14.8 \%$ for Delta, $\mathrm{p}<0.001)$. No difference was observed for time between symptom onset and ICU admission. Regarding vaccination status, 517 patients $(58 \%)$ did not receive any injection of vaccine. Omicron infected patients were more frequently vaccinated with at least one injection compared to Delta-positive patients (57.7\% versus $30.1 \%$, respectively, $\mathrm{p}<0.01)$. Differences between Delta and Omicron variant were also observed for patients who received 2 or 3 injections (Table 1). In patients who had at least 1 injection of vaccine, BNT162b2 or mRNA-1273 was used in $83.5 \%$ and other vaccines in $16.5 \%$ of cases, mostly chAdOx1 with no difference between the variant.

743 patients $(83.7 \%)$ were admitted to the ICU for pneumonia, while such admission was less frequent for Omicron cases $(67.2 \%$ versus $94.8 \%$ for Delta, $\mathrm{p}<0.001$, risk reduction of 29\%, Table 1). In Omicron infected patients, pneumonia was significantly less frequent in vaccinated than in unvaccinated patients $(62.1$ versus $80.7 \%, \mathrm{p}<0.001)$, while among the 60 Omicron infected patients who had 3 doses of vaccine, 43 (71.7\%) were admitted for pneumonia. A similar result, even less pronounced, was observed for Delta cases $(\mathrm{p}<0.01$ for vaccinated versus unvaccinated patients, Table 1). Finally, Omicron cases were less frequently invasively ventilated compared to Delta cases $(41.0 \%$ versus $51 \%$, respectively, $\mathrm{p}=0.02)$. Among patients already discharged from the ICU on January 18, 2021 (80\% of Delta cases and 
medRxiv preprint doi: https://doi.org/10.1101/2022.01.25.22269839; this version posted January 28,2022 . The copyright holder for this preprint (which was not certified by peer review) is the author/funder, who has granted medRxiv a license to display the preprint in All rights reserved. No reuse allowed without permission.

$63.6 \%$ of Omicron cases), unadjusted in-ICU mortality did not differ $(20.0 \%$ and $27.9 \%$ for Omicron and Delta, respectively, $\mathrm{p}=0.08$ ).

In the subgroup of 743 patients admitted to the ICU with pneumonia, 379 had the Delta variant and 154 the Omicron variant (Table 2). Omicron patients were significantly older (see also Figure 3), more frequently admitted to the ICU in the 5 days following symptom onset ( $p$ $=0.004)$ and less likely to be invasively ventilated (39\% versus $50.4 \%$ for Delta, p 0.021 ). InICU mortality did not differ in the $75 \%$ of patients already discharged on January 18,2022 (80\% of Delta cases were discharged and $63 \%$ of Omicron cases), and aHR for the type of variant was non-significant $(1.43,95 \% \mathrm{CI}[0.89 ; 2.29], \mathrm{p}=0.14)$.

\section{Discussion}

We report the impact of the Omicron variant on ICU admission in patients with COVID19 hospitalized in the APHP group between December 1, 2021 and January 18, 2022. Omicron patients were $64 \%$ less likely to be admitted to the ICU than Delta patients, and more than one half of Omicron infected patients stayed in the emergency department, compared to $39 \%$ of Delta infected patients. The rate of increase in patients admitted to the ICU and to the general medical ward showed a faster impact of Omicron on conventional hospitalization than on ICU admission, and Omicron tended to replace Delta more rapidly in the general medical ward than in the ICU. Such results were already suggested from observations in the UK and South Africa. ${ }^{4,5}$ On the other hand, we are able to report that almost one-third of patients hospitalized in the ICU of the APHP group between December 1, 2020 and January 18, 2021 already had the Omicron variant, with a rate of $45 \%$ on January 18. It is also noteworthy that patients infected with the Omicron variant were more frequently vaccinated than those with the Delta variant, mostly with an mRNA vaccine for both, even with the booster, which could suggest a lower efficacy of the vaccine. However, they were more immunocompromised and had a $29 \%$ 
medRxiv preprint doi: https://doi.org/10.1101/2022.01.25.22269839; this version posted January 28,2022 . The copyright holder for this preprint (which was not certified by peer review) is the author/funder, who has granted medRxiv a license to display the preprint in All rights reserved. No reuse allowed without permission.

reduction in risk of being admitted for COVID-19 pneumonia when they were vaccinated, which could suggest moderate protection of vaccination for the most severe form reported in ICU in unvaccinated patients. ${ }^{11}$ Admissions not due to pneumonia may be related to several causes, as patients admitted to the ICU with a positive RT-PCR but not for COVID-19, severe decompensation of a chronic disease due to direct SARS-CoV-2 infection or another disease pattern related to this new variant. It has been reported that Omicron replicates 10 times less in human lung tissue than the wild strain. ${ }^{12}$ Unfortunately, the design of our registry did not allow us to go further in the analysis.

On January 7, 2022, the Intensive Care National Audit and Research Center (ICNARC) reported epidemiological data about critically ill COVID-19 patients. ${ }^{13}$ There was a dissociation between the number of hospital admissions (significant increase) and in-ICU admission (quite stable) since December 2021. However, the comparison relates to two long periods of time, the first between September 1, 2020 and April 30, 2021, the second between May 12021 and January 7 2022, which makes it difficult to draw any conclusion regarding the new Omicron, which that emerged in December 2021. Above all, no information was given about the type of variant and so it was not possible to compare Delta and Omicron cases. ${ }^{13}$

With our prospective Reality database, we are able to provide new information on the comparison between Delta and Omicron cases. Besides the difference in vaccination status discussed above, Omicron patients were more frequently immunocompromised and less frequently invasively ventilated. Unadjusted in-ICU mortality was not different in the global population. More interestingly, among the subgroup of patients admitted to the ICU for pneumonia only, Omicron cases seem to be as severe as Delta cases, with no difference observed in the adjusted risk of mortality. However, Omicron patients were still less invasively ventilated than Delta cases, which could be explained by still more immunocompromised patients. ${ }^{10}$ Among patients admitted for pneumonia, we noted a relatively low rate of invasive 
medRxiv preprint doi: https://doi.org/10.1101/2022.01.25.22269839; this version posted January 28, 2022. The copyright holder for this preprint (which was not certified by peer review) is the author/funder, who has granted medRxiv a license to display the preprint in All rights reserved. No reuse allowed without permission.

ventilation (40-50\% of cases), which could be explained first because ICUs in the APHP group usually include a mix of full ICU beds and of intermediate beds for less critically ill patients, and second because compared to the first wave, some studies have now suggested the beneficial effect of high-flow oxygen saturation ${ }^{14,15}$ and non-invasive ventilation ${ }^{16}$ on the requirement for invasive ventilation and on recovery, which probably led to changes in practices.

Our study has some limitations. First, there was a discrepancy between the numbers of critically ill patients with the Delta or Omicron variant in the Reality registry (629 patients) and in the administrative databases (579 patients). As noted in the methods section, the explanation is that all but one hospital of the APHP group collected patient information in the laboratory information system. In Reality, variant screening test information was missing in $18 \%$ of cases, which could be explained by the fact that numerous patients were transferred to the ICU from another non-APHP hospital where they had already tested positive. As the test was not performed again we were not able to characterize the variant. Second, we did not have the time between the last injection of vaccine and admission to the ICU, which could limit our evaluation of the impact of vaccination on the Omicron variant. Third, in the adjusted risk of in-ICU mortality evaluation, some confounding factors may not have been taken into account and we do not have information on "do-not-intubate" decision in some patients. Finally, while to our knowledge we report here the largest cohort of critically ill patients comparing Delta and Omicron variant, our results should be confirmed in a larger cohort. A significant number of patients are still in the ICU, especially with the Omicron variant, which precludes any definitive conclusion regarding their respective outcomes. ${ }^{17}$

In conclusion, our study reports contrasting results. On the one hand, Omicron infected patients are less likely to be admitted to the ICU and when admitted, less often for pneumonia. On the other hand, vaccination even with 3 doses had a moderate protective effect against admission for pneumonia in patients who were more immunocompromised. Moreover, when 
medRxiv preprint doi: https://doi.org/10.1101/2022.01.25.22269839; this version posted January $28,2022$. The copyright holder for this preprint (which was not certified by peer review) is the author/funder, who has granted medRxiv a license to display the preprint in All rights reserved. No reuse allowed without permission.

admitted to the ICU for pneumonia, disease severity appears to be similar to that of Delta, with no difference in the adjusted risk of in-ICU mortality. Further studies are needed to evaluate its outcome. 
medRxiv preprint doi: https://doi.org/10.1101/2022.01.25.22269839; this version posted January 28,2022 . The copyright holder for this preprint (which was not certified by peer review) is the author/funder, who has granted medRxiv a license to display the preprint in All rights reserved. No reuse allowed without permission.

\section{Author contributions}

All authors contributed, directly or indirectly, to entering critically ill patients in the Reality database.

A Vieillard-Baron and F Batteux created the Reality prospective registry, analyzed the results and wrote the manuscript.

A Vieillard-Baron designed the study.

F Batteux, R Flicoteaux and B De Maupeou D’Ableiges performed the statistical analysis.

All authors confirm that they had full access to all of the study data and accept responsibility to submit for publication. They all agree with the manuscript.

\section{Declaration of interest}

Dr. Vieillard-Baron declares a research grant from Air Liquide.

Dr. Mebazaa reports personal fees from Orion, Servier, Otsuka, Philips, Sanofi, Adrenomed, Epygon and Fire 1 and grants and personal fees from 4TEEN4, Abbott, Roche and Sphyngotec. Dr. Gayat declares personal fees from Baxter and Edwards and research grants from Radiometer and Philips.

Dr. Chousterman declares being a member of an advisory board for Roche diagnostic and has received speaker fees from Baxter.

Dr. Demoule reports grants, personal fees and non-financial support from Philips, personal fees from Baxter, personal fees and non-financial support from Fisher \& Paykel, grants from the French Ministry of Health, personal fees from Getinge, grants, personal fees and non-financial support from Respinor, grants, personal fees and non-financial support from Lungpacer, personal fees from Lowenstein, and personal fees from Gilead.

Dr. Teboul declares being a member of the medical advisory board of Getinge and personal speaker fees from Lilly. 
medRxiv preprint doi: https://doi.org/10.1101/2022.01.25.22269839; this version posted January 28,2022 . The copyright holder for this preprint (which was not certified by peer review) is the author/funder, who has granted medRxiv a license to display the preprint in All rights reserved. No reuse allowed without permission.

Dr. Cariou declares speaker fees from Bard.

Bernard Cholley has received honoraria (participation in advisory boards) or lecturing fees from Orion Pharma, Edwards Life Sciences, Amomed, and Nordic pharma.

Elie Azoulay has received speaker fees and research grants from Sanofi, Alexion and Pfizer. Sébastien Clerc has received financial support (registration at an international meeting) from Oxyvie.

Nicolas Mongardon declares being member of an advisory board of Amomed.

The other authors do not declare any conflicts of interest.

\section{Acknowledgments}

We thank the "Direction de la recherche clinique et de l'innovation (DRCI)" of APHP group for providing extensive data.

We thank Guillermo Hayoun from the "Direction des systèmes de l'information" for his work in designing and updating the Reality registry when necessary.

We thank Laure Maillant of the health database of APHP ("Entrepôt de Données en Santé") for her help in generating the data.

Finally, we also thank all the virology laboratories of the APHP group, which helped with the RT-PCR screening of our patients.

\section{Funding source}

Assistance Publique des Hôpitaux de Paris, APHP.

The funder of the study had no role in study design, data analysis, data interpretation, or writing of the report. All authors had full access to all data in the study and had final responsibility for the decision to submit for publication. 
medRxiv preprint doi: https://doi.org/10.1101/2022.01.25.22269839; this version posted January 28,2022 . The copyright holder for this preprint (which was not certified by peer review) is the author/funder, who has granted medRxiv a license to display the preprint in All rights reserved. No reuse allowed without permission.

\section{References}

1- Abdool Karim SS, Abdool Karim Q. Omicron SARS-CoV-2 variant: a new chapter in the COVID-19 pandemic. Lancet 2021; 38: 2126-2128

2- World Health Organization (WHO): What you need to know about the new Omicron COVID-19 variant. Available at: https://www.euro.who.int/ en/health-topics/healthemergencies/coronavirus-covid-19/news/news/2021/12/what-you-needto-know-aboutthe-new-omicron-covid-19-variant. Cited date December 9, 2021

3- Santé Publique France. Chiffres clés et evolution de la COVID en France et dans le Monde. https://www.santepubliquefrance.fr/

4- Ferguson N, Ghani A, Hinsley W, Volz E on behalf of the Imperial College COVID19 response team. Report 50: Hospitalisation and risk for Omicron cases in England. DOI: https://doi.org/10.25561/93035

5- Wolter N, Jassat W, Walaza S, et al; Early assessment of the clinical severity of the SARS-CoV-2 omicron variant in South Africa: a data linkage study. Lancet 2022; doi.org/10.1016/S0140-6736(22)00017-4

6- Maslo C, Friedland R, Toubkin M, Laubscher A, Akaloo T, Kama B. Characteristics and ouctomes of hospitalized patients in South Africa during the COVID-19 Omicron wave compared with previous waves. Jama 2021; e2124868. doi:

10.1001/jama.2021.24868

7- Raux M, Carli P, Lapostolle F, et al. Analysis of the medical response to November 2015 Paris terrorist attacks: resource utilization according to the cause of injury. Intensive Care med 2019; 45: 1231-40

8- The COVID-19 APHP group. Assistance Publique des Hôpitaux de Paris' response to the COVID-19 pandemic. Lancet 2020; $395: 1760-1761$ 
medRxiv preprint doi: https://doi.org/10.1101/2022.01.25.22269839; this version posted January 28,2022 . The copyright holder for this preprint (which was not certified by peer review) is the author/funder, who has granted medRxiv a license to display the preprint in All rights reserved. No reuse allowed without permission.

9- Viana R, Moyo S, Amoako D, et al. Rapid epidemic expansion of the SARS-CoV-2 Omicron variant in southern Africa. Nature 2021; doi.org/10.1038/d41586-021-038325

10- Azoulay E, Mokart D, Kouatchet A, et al. Acute respiratory failure in immunocompromised adults. Lancet respire Med 2019; 7: 173-186

11-Tenforde MW, Self W, Adams K, et al. Association between mRNA vaccination and COVID-19 hospitalization and disease severity. Jama 2021; 326: 2043-2054

12-LKS Faculty of Medicine, HKUMed. HKUMed finds Omicron SARS-Cov-2 can infect faster and better than Delta in humans but with less severe infection in lung. https://www.med.hku.hk/en/news/press/20211215-omicron-sars-cov-2-infection

13- The Intensive Care National Audit and Research Center. Report 2022-01-07. https://www.icnarc.org/our-audit/audits/cmp/reports

14- Ospina-Tascon G, Calderon-Tapia L, Garcia A, et al. Effect of high-flow oxygen therapy vs conventional oxygen therapy on invasive mechanical ventilation and clinical recovery in patients with severe COVID-19: a randomized clinical trial. Jama 2021; 326: 2161-2171

15-Demoule A, Vieillard-Baron A, Darmon M, et al. High-flow nasal cannula in critically ill patients with severe COVID-19. Am J Respir Crit Care Med 2020; 202: 1039-1042

16- Perkins G, Ji C, Connolly B, et al. Effect of noninvasive respiratory strategies on intubation or mortality among patients with acute hypoxemic respiratory failure and COVID-19. The RECOVERY-RS randomized clinical trial. Jama 2022; doi: 10.1001/jama.2022.0028

17-Lapidus N, Zhou X, Carrat F, Riou B, Zhao, Y, Hejblum G. Biased and unbiased estimation of the average length of stay in intensive care units in the Covid-19 pandemic. Ann Intensive Care 2020; 10:135 
medRxiv preprint doi: https://doi.org/10.1101/2022.01.25.22269839; this version posted January $28,2022$. The copyright holder for this preprint (which was not certified by peer review) is the author/funder, who has granted medRxiv a license to display the preprint in All rights reserved. No reuse allowed without permission.

\section{Figure legends}

Figure 1: Study flow chart for the 5140 RT-PCR positive patients between December 1, 2021 and January 18, 2022 according to the Omicron and Delta variants and their respective evolution. ED: emergency department.

Figure 2: Respective dynamics of the Delta and Omicron variants for new daily ICU admissions (panel A) and the actual number of patients in the ICU during the study period (panel B). Panels C and D report the same information for conventional hospitalization.

Figure 3: Proportion of pneumonia cases in critically ill patients with the Delta and Omicron variant according to age. 
medRxiv preprint doi: https://doi.org/10.1101/2022.01.25.22269839; this version posted January $28,2022$. The copyright holder for this preprint (which was not certified by peer review) is the author/funder, who has granted medRxiv a license to display the preprint in perpetuity.

All rights reserved. No reuse allowed without permission.

Table 1: Characteristics of critically ill patients according to Omicron versus Delta variant in the 888 patients included in the Reality database from December 1, 2021 to January 18, 2022.

\begin{tabular}{|c|c|c|c|c|c|}
\hline & $\begin{array}{l}\text { Delta cases } \\
\qquad \begin{array}{c}\mathrm{N}=\mathbf{4 0 0} \\
(45 \%)\end{array}\end{array}$ & $\begin{array}{l}\text { Omicron cases } \\
\qquad \begin{array}{c}\mathrm{N}=229 \\
(25.8 \%)\end{array}\end{array}$ & $\begin{array}{c}\text { P value } \\
\text { (Delta } \\
\text { versus } \\
\text { Omicron) }\end{array}$ & $\begin{array}{l}\text { Uninformative } \\
\text { screening test* } \\
\qquad \begin{array}{c}\mathrm{N}=98 \\
(11 \%)\end{array}\end{array}$ & $\begin{array}{l}\text { Missing data** } \\
\qquad \begin{array}{c}\mathrm{N}=161 \\
(18 \%)\end{array}\end{array}$ \\
\hline Age & $62.0[51.0 ; 70.0]$ & $63.0[49.0 ; 71.0]$ & 0.810 & $59.0[45.5 ; 64.8]$ & $62.0[49.0 ; 70.0]$ \\
\hline \multicolumn{6}{|l|}{ Sex } \\
\hline Female, n (\%) & $135(33.8 \%)$ & $75(32.8 \%)$ & 0.867 & $28(28.6 \%)$ & $56(34.8 \%)$ \\
\hline Male, n (\%) & $265(66.2 \%)$ & $154(67.2 \%)$ & & $70(71.4 \%)$ & $105(65.2 \%)$ \\
\hline Vaccination, n (\%) & & & $<0.001$ & & \\
\hline 0 injection & $279(69.8 \%)$ & $83(36.2 \%)$ & & $46(46.9 \%)$ & $109(67.7 \%)$ \\
\hline 1 injection & $19(4.8 \%)$ & $13(5.7 \%)$ & & $4(4.08 \%)$ & $5(3.11 \%)$ \\
\hline 2 injections & $58(14.5 \%)$ & $59(25.8 \%)$ & & $20(20.4 \%)$ & $25(15.5 \%)$ \\
\hline 3 injections & $43(10.8 \%)$ & $60(26.2 \%)$ & & $20(20.4 \%)$ & $17(10.6 \%)$ \\
\hline Unknown & $1(0.3 \%)$ & $14(6.1 \%)$ & & $8(8.2 \%)$ & $5(3.1 \%)$ \\
\hline Immunocompromised, n (\%) & $59(14.8 \%)$ & $79(34.5 \%)$ & $<0.001$ & $19(19.6 \%)$ & $21(13.2 \%)$ \\
\hline $\begin{array}{l}\text { Time from symptoms onset to } \\
\text { ICU admission }\end{array}$ & & & 0.061 & & \\
\hline$\leq 5$ days & $69(17.2 \%)$ & $52(22.7 \%)$ & & $15(15.3 \%)$ & $34(21.1 \%)$ \\
\hline$>5$ days & $316(79.0 \%)$ & $158(69.0 \%)$ & & $78(79.6 \%)$ & $121(75.2 \%)$ \\
\hline Unknown & $15(3.8 \%)$ & $19(8.3 \%)$ & & $5(5.1 \%)$ & $6(3.73 \%)$ \\
\hline Pneumonia, n (\%) & $379(94.8 \%)$ & $154(67.2 \%)$ & $<0.001$ & $69(70.4 \%)$ & $141(87.6 \%)$ \\
\hline \multirow[t]{2}{*}{ Unvaccinated, n (\%) } & $273 / 279$ & $67 / 83$ & & - & - \\
\hline & $(97.8 \%)$ & $(80.7 \%)$ & & - & - \\
\hline \multirow[t]{2}{*}{ Vaccinated, n (\%) } & $105 / 120$ & $82 / 132$ & & - & - \\
\hline & $(87.5 \%)^{\$}$ & $(62.1 \%)^{£}$ & & - & - \\
\hline Unknown, n & 1 & 5 & & - & - \\
\hline Invasive ventilation, $\mathrm{n}(\%)$ & $204(51.0 \%)$ & $94(41.0 \%)$ & 0.020 & $34(34.7 \%)$ & $71(44.1 \%)$ \\
\hline In-ICU mortality, n (\%) & $90 / 323(27.9 \%)$ & $31 / 155(20.0 \%)$ & 0.082 & $11 / 78(14.1 \%)$ & $35 / 139(25.2 \%)$ \\
\hline
\end{tabular}

Continuous values are reported as median [Q2, Q3].

* Variant Screening test was impossible because the viral load was not sufficient. ** Missing data means that variant-screening was not performed. ${ }^{\$} \mathrm{p}<0.001$ for incidence of pneumonia in vaccinated versus nonvaccinated patients with Delta, ${ }^{£} \mathrm{p}<0.001$ for incidence of pneumonia in vaccinated versus non-vaccinated patients with Omicron. 
medRxiv preprint doi: https://doi.org/10.1101/2022.01.25.22269839; this version posted January $28,2022$. The copyright holder for this preprint (which was not certified by peer review) is the author/funder, who has granted medRxiv a license to display the preprint in All rights reserved. No reuse allowed without permission.

Table 2: Characteristics of critically ill patients according to Omicron versus Delta variant in the subgroups of 743 patients admitted in ICU for pneumonia from December 1, 2021 to January 18, 2022.

\begin{tabular}{|c|c|c|c|c|c|}
\hline & $\begin{array}{l}\text { Delta cases } \\
\qquad N=379\end{array}$ & $\begin{array}{l}\text { Omicron cases } \\
\qquad \begin{array}{l}\mathrm{N}=154\end{array}\end{array}$ & $\begin{array}{c}\text { P value } \\
\text { (Delta } \\
\text { versus } \\
\text { Omicron) }\end{array}$ & $\begin{array}{c}\text { Uninformative } \\
\text { screening test* } \\
\text { N=69 }\end{array}$ & $\begin{array}{l}\text { Missing data** }^{* *} \\
\qquad \mathbf{N}=141\end{array}$ \\
\hline Age & $62.0[51.0 ; 70.0]$ & $65.0[56.0 ; 72.0]$ & 0.033 & $60.0[56.0 ; 65.0]$ & $62.0[50.0 ; 70.0]$ \\
\hline Female, n (\%) & $126(33.2 \%)$ & $56(36.4 \%)$ & 0.557 & $20(29.0 \%)$ & $49(34.8 \%)$ \\
\hline $\begin{array}{l}\text { Immunocompromised, } \\
\text { n (\%) }\end{array}$ & $56(14.8 \%)$ & $61(39.6 \%)$ & $<0.001$ & $16(23.2 \%)$ & $17(12.0 \%)$ \\
\hline $\begin{array}{l}\text { Time from symptoms onset to } \\
\text { ICU admission, } \mathrm{n}(\%)\end{array}$ & & & 0.004 & & \\
\hline$\leq 5$ days & $61(16.1 \%)$ & $42(27.3 \%)$ & & $12(17.4 \%)$ & $30(21.3 \%)$ \\
\hline$>5$ days & $303(80.0 \%)$ & $105(68.2 \%)$ & & $56(81.2 \%)$ & $107(75.9 \%)$ \\
\hline Unknown & $15(4.0 \%)$ & $7(4.5 \%)$ & & $1(1.4 \%)$ & $4(2.8 \%)$ \\
\hline $\begin{array}{l}\text { Invasive ventilation, } \mathrm{n} \\
(\%)\end{array}$ & $191(50.4 \%)$ & $60(39.0 \%)$ & 0.021 & $23(33.3 \%)$ & $62(44.0 \%)$ \\
\hline In-ICU mortality, n (\%) & 90/303 (29.7\%) & $31 / 98(31.6 \%)$ & 0.780 & $10 / 54(18.5 \%)$ & $35 / 120(29.2 \%)$ \\
\hline
\end{tabular}

Continuous values are reported as median [Q2, Q3].

* Variant Screening test was impossible because the viral load was not sufficient. ** Missing data means that variant-screening was not performed.

In-ICU mortality was calculated among the 303 Delta patients (80\%) and the 98 Omicron patients $(63.6 \%)$ who were already discharged from the ICU. 
medRxiv preprint doi: https://doi.org/10.1101/2022.01.25.22269839; this version posted January $28,2022$. The copyright holder for this preprint (which was not certified by peer review) is the author/funder, who has granted medRxiv a license to display the preprint in All rights reserved. No reuse allowed without permission. 
medRxiv preprint doi: https://doi.org/10.1101/2022.01.25.22269839; this version posted January $28,2022$. The copyright holder for this preprint (which was not certified by peer review) is the author/funder, who has granted medRxiv a license to display the preprint in

perpetuity.
All rights reserved. No reuse allowed without permission.

\section{Figure 1}

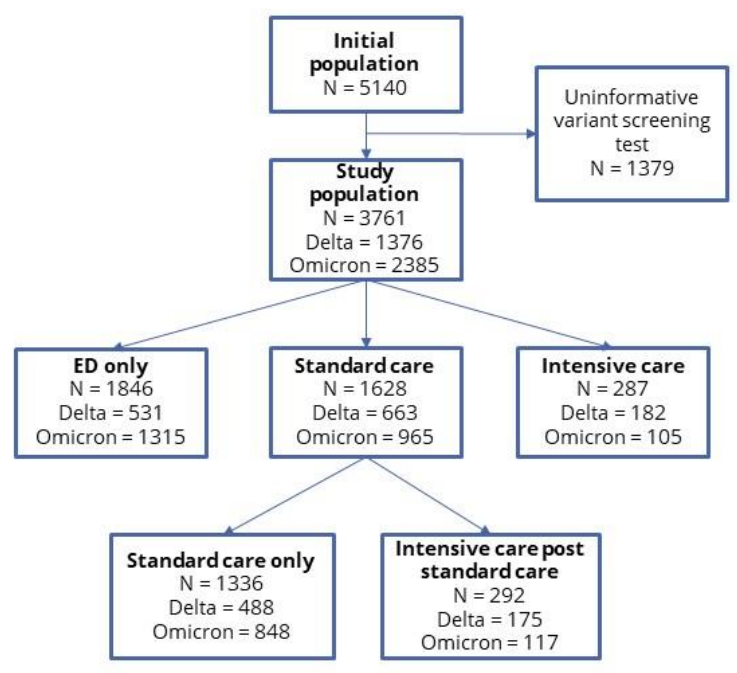


medRxiv preprint doi: https://doi.org/10.1101/2022.01.25.22269839; this version posted January $28,2022$. The copyright holder for this preprint (which was not certified by peer review) is the author/funder, who has granted medRxiv a license to display the preprint in All rights reserved. No reuse allowed without permission.

Figure 2

$\begin{aligned} \text { ICU admissions } & =\text { Delta variant } \\ & =\begin{array}{l}\text { Omicron variant } \\ \text { Uninformative variant screening test }\end{array}\end{aligned}$

A

Number of patients

B

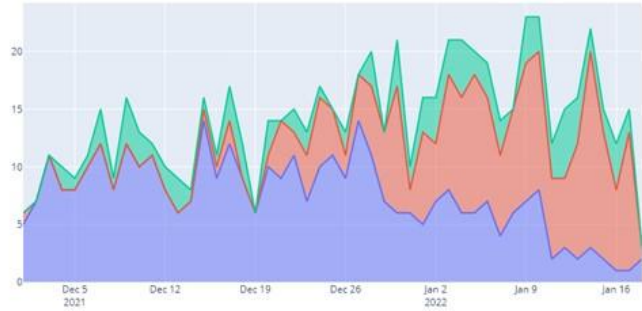

Number of patients

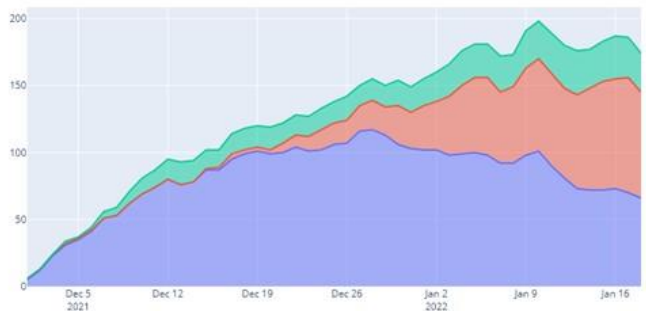

C

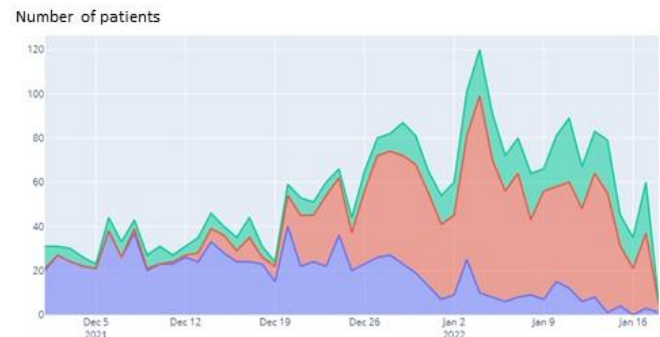

Number of patients

$16.7 \% \quad$ D

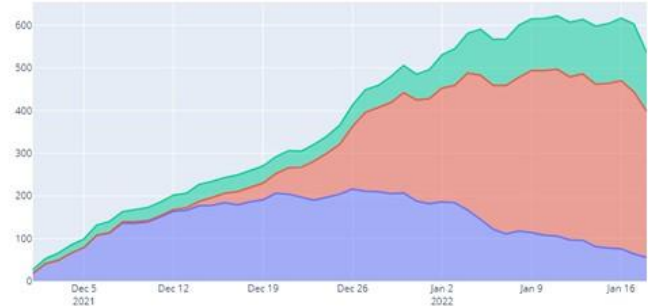

$25.8 \%$

$63.8 \%$ $10.4 \%$ 
medRxiv preprint doi: https://doi.org/10.1101/2022.01.25.22269839; this version posted January $28,2022$. The copyright holder for this preprint (which was not certified by peer review) is the author/funder, who has granted medRxiv a license to display the preprint in All rights reserved perpetuity.

Figure 3

Age distribution and pneumonia status : Delta, $n=400$

$$
\text { Pneumonia }
$$

A

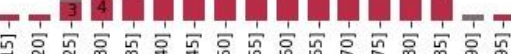

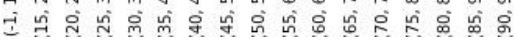

Age distribution and pneumonia status: Omicron, $n=229$

- Pneumonia

No pneumonia

B

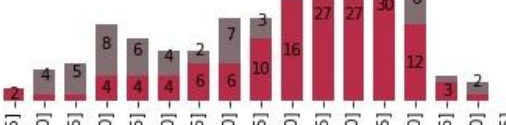

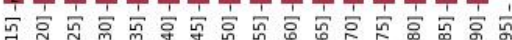

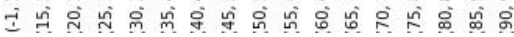

